\title{
The executioners sing a new song: killer caspases activate microglia
}

\author{
JL Venero ${ }^{1}$, MA Burguillos ${ }^{2,3}$, P Brundin ${ }^{3}$ and B Joseph ${ }^{\star, 2}$
}

Activation of microglia and inflammation-mediated neurotoxicity are suggested to have key roles in the pathogenesis of several neurodegenerative disorders. We recently published an article in Nature revealing an unexpected role for executioner caspases in the microglia activation process. We showed that caspases 8 and $3 / 7$, commonly known to have executioner roles for apoptosis, can promote microglia activation in the absence of death. We found these caspases to be activated in microglia of PD and $A D$ subjects. Inhibition of this signaling pathway hindered microglia activation and importantly reduced neurotoxicity in cell and animal models of disease. Here we review evidence suggesting that microglia can have a key role in the pathology of neurodegenerative disorders. We discuss possible underlying mechanisms regulating their activation and neurotoxic effect. We focus on the provocative hypothesis that caspase inhibition can be neuroprotective by targeting the microglia rather than the neurons themselves.

Cell Death and Differentiation (2011) 18, 1679-1691; doi:10.1038/cdd.2011.107; published online 12 August 2011

\section{Microglia, the Guardians of the Brain}

The brain is partially isolated from the bloodstream by the blood-brain barrier, which prevents infections from affecting several vital brain functions. For this reason, brain and spinal cord were considered 'immune-privileged' organs in that they are separated from the rest of the body.

Several different types of neuroglia participate in multiple CNS activities, from structural and metabolic functions to information processing. They also seem to be involved in the progression of neurodegenerative diseases. Neuroglial cells are divided into different subtypes, which include astrocytes, oligodendrocytes, NG2 glial cells and microglia.

Microglia are CNS macrophages first described by Rio-Hortega, a disciple of Ramón y Cajal, in 1919. ${ }^{1}$ Microglia populate the mammalian CNS in early embryonic development. By adulthood, microglia are found in all regions of the brain and spinal cord, and comprise $10-15 \%$ of all CNS cells. Microglia are the immune cells of the CNS - the guardians of the brain - constantly scavenging for damaged neurons, plaques and infectious agents by using their multiple surface receptors. In addition to being sensitive to changes in their environment, each microglial cell also regularly physically surveys its domain. While moving through its precinct, if the microglial cell finds any invading viruses, bacteria, damaged cells, apoptotic cells, neural tangles, DNA fragments or plaques it will undergo activation and phagocytize the material or cell. Thereby microglial cells also act as 'housekeepers' that clean up the brain. Thus, microglial cells fulfill an astonishing variety of tasks within the CNS (Box 1, FACTS).

Originally, the non-activated microglia were designated as 'resting', but nowadays the term 'surveying' is preferred, reflecting the more dynamic nature of these cells. When microglia are 'activated' they take on an amoeboid shape and increase their gene expression, leading to the production of numerous potentially neurotoxic mediators. During recent years, researchers have tended to differentiate between

\footnotetext{
${ }^{1}$ Facultad de Farmacia, Departamento de Bioquímica y Biología Molecular, Universidad de Sevilla, and Instituto de Biomedicina de Sevilla (IBiS), Sevilla, Spain; ${ }^{2}$ Department of Oncology-Pathology, Cancer Centrum Karolinska, Karolinska Institutet, Stockholm SE-171 76, Sweden and ${ }^{3}$ Neuronal Survival Unit, Department of Experimental Medical Science, Wallenberg Neuroscience Center, Lund 221 84, Sweden

${ }^{*}$ Corresponding author: B Joseph, Department of Oncology-Pathology, Cancer Centrum Karolinska, Karolinska Institutet, Stockholm SE-171 76, Sweden.

Tel: + 468517738 26; Fax: + 4683390 31; E-mail: bertrand.joseph@ki.se

Keywords: microglia; caspases; neurodegenerative disorders

Abbreviations: $\mathrm{A} \beta, \beta$-amyloid; AD, Alzheimer's disease; AIM2, absent in melanoma-2; ALS, amyotrophic lateral sclerosis; AMPA receptor, $\alpha$-amino-3-hydroxy-5methyl-4-isoxazolepropionic acid receptor; AP-1, activator protein-1; APP, amyloid- $\beta$ precursor protein; CoREST, REST co-repressor; COX, cyclooxygenase; DA, dopaminergic; DAMP, danger-associated molecular pattern; fmk, fluoromethyl ketone; GSK3 $\beta$, glycogen synthase kinase-3 $\beta$; HD, Huntington's disease; HSP, heatshock proteins; IL, interleukin; IL-1R, IL-1 receptor; IFN- $\gamma$, interferon- $\gamma$; IFNGR, IFN- $\gamma$ receptor; IKK $\varepsilon$, I $\kappa$ B kinase- $\varepsilon$; iNOS, inducible nitric oxide synthase; IRAK, interleukin receptor-associated kinase; IRF, interferon-regulatory factor; Jak, Janus kinase; LPS, lipopolysaccharide; LTA, lipoteichoic acid; LRR, leucine-rich repeat; MAPK, mitogen-activated protein kinase; MHC, major histocompatibility complex; MMP, matrix metalloproteinase; MPTP, 1-methyl-4-phenyl-1,2,3,6-tetrahydropyridine; MS, multiple sclerosis; MyD88, myeloid differentiation factor-88; NEMO, NF- $\kappa$ B essential modulator; NF- $\kappa$ B, nuclear factor $\kappa$-light-chain enhancer of activated B cells; NLRP, NLR family pyrin domain containing; NO, nitric oxide; $\mathrm{O}_{2}^{-}$, superoxide anion; Nurr-1, nuclear receptor related-1 protein; PAMP, pathogen-associated molecular pattern; PD, Parkinson's disease; PKC $\delta$, protein kinase-C $\delta$; Q-VD-OPh, quinolyl-valyl-O-methylaspartyl-[-2,6-difluorophenoxy]-methylketone; RAGEs, receptors like advanced glycation end products; ROS, reactive oxygen species; SN, substantia nigra; Socs, suppressors of cytokine signaling proteins; STAT, signal transducer and activator of transcription; TANK, TRAF family member-associated NFKB activator; TBK1, TANK-binding kinase-1; TIR, Toll-interleukin-1 receptor; TLR, Toll-like receptor; TNF- $\alpha$, tumor necrosis factor- $\alpha$; TRAF6, TNF receptor-associated factor-6; TIRAP, TIR domain-containing adaptor protein; TRAM, TRIF-related adapter molecule; TRIF, TIR-domain-containing, adapter-inducing interferon- $\beta$; Tyk2, tyrosine kinase-2
}

Received 26.4.11; revised 09.6.11; accepted 21.6.11; Edited by G Melino; published online 12.8.11 
FACTS:

- Under physiological conditions, microglia cells serve as surveyors of the integrity and function of the brain. However, their function changes under pathological conditions, during which microglia can have either a supportive or a detrimental role for neuronal survival.

- Upon activation, microglia cells release proinflammatory factors (that is, cytokines), reactive oxygen/nitrogen species and proteases that eventually provoke neuronal demise and death.

- Several signaling pathways lead to microglial activation. Depending on the nature of the proinflammatory stimulus they can include TLRs, MyD88, JAK/STAT and NF- $\kappa$ B.

- Recent studies indicate that killer caspases can take on non-apoptotic roles. For example, caspases 8 and $3 / 7$, commonly known as executioners of apoptosis, can promote microglia activation in the absence of cell death.

- Caspases 8 and 3/7 are activated in microglia in the substantia nigra in Parkinson's disease subjects and the frontal cortex of Alzheimer's disease subjects.

- Caspase inhibitors exert neuroprotective effects in several animal models of neurodegenerative disorders, which are characterized by reactive microgliosis.

Table 1 Innate and adaptive immune responses in chronic neurodegenerative diseases

\begin{tabular}{|c|c|c|c|}
\hline & Innate immune response & Adaptive immune response & References \\
\hline $\begin{array}{l}\text { Parkinson's } \\
\text { disease }\end{array}$ & $\begin{array}{l}\text { - Microgliosis } \\
\text { - Activation of cleaved caspase-8 and caspase-3 } \\
\text { in reactive microglia } \\
\text { - Release of matrix metalloproteinase-3, } \alpha \text {-synuclein } \\
\text { and neuromelanin } \\
\text { - Increased proinflammatory cytokines and } \\
\text { ROS-generating enzymes: TNF- } \alpha, \text { IL-1 } \beta, \text { IL-2, 4, 6, iNOS, } \\
\text { COX-2, NADPH oxidase } \\
\text { - Upregulation of CD14, TLR2, TLR5 }\end{array}$ & $\begin{array}{l}\text { - Cytotoxic T-lymphocytes in the } \\
\text { parkinsonian brain } \\
\text { - Suspected FasL-dependent mechanism } \\
\text { to trigger cell death of dopaminergic } \\
\text { neurons in the substantia nigra }\end{array}$ & $\begin{array}{l}4,5,8,10,13,14 \\
18,21,103-105\end{array}$ \\
\hline $\begin{array}{l}\text { Alzheimer's } \\
\text { disease }\end{array}$ & $\begin{array}{l}\text { - Microgliosis } \\
\text { - Activation of cleaved caspase-8 and caspase-3 } \\
\text { in reactive microglia } \\
\text { - Release of proinflammatory toxic A } \beta \text { peptides } \\
\text { Increased proinflammatory cytokines and } \\
\text { ROS-generating enzymes: IL-1 } \beta \text {, IL-6, iNOS, IL-18, } \\
\text { prostanglandins, COX-2, TNF- } \alpha \\
\text { Increased complement components, chemokines } \\
\text { and TGF- } \beta \\
\text { Upregulation of CD14, TLR2 and TLR4 microglial } \\
\text { receptors }\end{array}$ & - Uncertain & $\begin{array}{l}8,13-18,104 \\
106-108\end{array}$ \\
\hline $\begin{array}{l}\text { Amyotrophic } \\
\text { lateral } \\
\text { sclerosis }\end{array}$ & $\begin{array}{l}\text { Microgliosis } \\
\text { Increased proinflammatory cytokines IL-6, IL-1 } \beta \\
\text { and TNF- } \alpha \text { elevated in the cerebrospinal fluid } \\
\text { and/or spinal cord } \\
\text { - Upregulation of COX-2 in spinal cord }\end{array}$ & - T-lymphocytes at sites of lesion & $109-112$ \\
\hline $\begin{array}{l}\text { Multiple } \\
\text { sclerosis }\end{array}$ & $\begin{array}{l}\text { - Microgliosis } \\
\text { - Presence of macrophages digesting myelin } \\
\text { at the lesion edge } \\
\text { immunoglobulin and complement deposits found } \\
\text { in } 50 \% \text { of cases }\end{array}$ & $\begin{array}{l}\text { - Lymphocytes and activated myeloid } \\
\text { cells at sites of lesion }\end{array}$ & $113-115$ \\
\hline
\end{tabular}

Abbreviations: $\mathrm{A} \beta, \beta$-amyloid; COX, cyclooxygenase; IL, interleukin; iNOS, inducible nitric oxide synthase; ROS, radical oxygen species; TGF, transforming growth factor; TLR, toll-like receptor; TNF, tumor necrosis factor.

acute inflammation and chronic inflammation, and their effects on neurons. It is widely accepted that sustained inflammation is deleterious to neurons, a typical feature of chronic neurodegenerative diseases including Parkinson's disease (PD) and Alzheimer's disease (AD).

\section{Microglia Turn Bad: Role for Microglia Activation in Neurodegenerative Diseases}

Activated microglia have key roles in neuroinflammation, and depending on the nature of the initial stimulus their actions may be either beneficial or detrimental to neuronal function. In chronic neurodegenerative diseases, microglia 'turn bad' and remain activated for an extended period during which the production of mediators is sustained longer than usual. This increase in mediators contributes to neuronal death. Activated microglia have been increasingly linked to various neurodegenerative diseases (Table 1 ). We recently described their involvement in the two most common forms of neurodegenerative disease, $P D$ and $A D$.

Parkinson's disease. Classical reports state that PD is characterized by a clinical syndrome of hypokinesia, rigidity 
and tremor. Most probably the motor dysfunction can be largely attributed to the progressive degeneration of dopaminergic (DA) neurons in the substantia nigra (SN). ${ }^{2}$ Relatively rare familial forms of $\mathrm{PD}$ are associated with mutations in genes encoding several proteins, including $\alpha$-synuclein, parkin and ubiquitin $\mathrm{C}$-terminal hydrolase- $\mathrm{L} 1{ }^{3}$ However, the etiology of idiopathic PD, which accounts for more than $90 \%$ of PD, is still not understood. ${ }^{2}$ The first indications for a role of inflammation in the pathogenesis of PD came from studies demonstrating the presence of cytotoxic T-lymphocytes and reactive microglia in the parkinsonian brain. ${ }^{4,5}$ Studies on brains from humans ${ }^{4}$ who had self-administered 1-methyl-4-phenyl-1,2,3,6-tetrahydropyridine (MPTP), and monkeys ${ }^{6}$ receiving the same toxin, revealed a striking microglial activation along with significant accumulation of extraneuronal neuromelanin, which can activate microglia. These findings established that an acute neurotoxic insult to the nigrostriatal system can result in longterm inflammatory response involving a reactive microgliosis and possibly leading to a self-perpetuating process of neurodegeneration. ${ }^{4}$ Several lines of evidence suggest that reactive microgliosis is deleterious to the DA neurons in the SN. Thus, a single intra-nigral injection of lipopolysaccharide (LPS), the main component of the cell walls of Gram-negative bacteria and a potent inductor of inflammation, induces an acute inflammatory response with a strong macrophage/microglial reaction. This leads to the progressive death of DA neurons in the $\mathrm{SN}^{7}$ Matrix metalloproteinase-3 (MMP3), $\alpha$-synuclein and neuromelanin are released by damaged DA neurons, leading to the production of reactive oxygen species (ROS) by overactivated microglia. ${ }^{8}$ Mice lacking the protein parkin, which is encoded by a gene associated with autosomal recessive young onset $P D$, show more severe nigral cell loss following systemic LPS treatment than controls, thus providing a link between a certain inherited form of PD with neuroinflammation. $^{9}$ Regardless of the nature of the proinflammatory stimulus (proinflammatory toxin, neuronal death, extracellular neuromelanin or $\alpha$-synuclein), the microglial response to neuron damage can lead to further loss of neurons over time. The presence of T-lymphocytes in the midbrain of $P D$ patients supports a role of peripheral inflammation in the etiopathology of PD. ${ }^{5}$ Other studies have demonstrated that (i) T-lymphocytes mediate nigral DA neurotoxicity through an FasL-dependent mechanism ${ }^{10}$ and (ii) peripheral inflammation induced by a single systemic LPS injection triggers persistent microglia activation in different brain areas, including the $\mathrm{SN}$, and that $\mathrm{DA}$ neurons progressively die later. ${ }^{11}$
Alzheimer's disease. The primary clinical presentation of $A D$ is progressive cognitive decline, with memory loss being an early sign. ${ }^{12}$ The $A D$ brain shows prominent atrophic changes in the hippocampal, frontal, parietal and temporal areas as a consequence of extensive synaptic degeneration and neuronal death. ${ }^{12}$ Furthermore, the AD brain is characterized by extracellular accumulation of $\beta$-amyloid $(\mathrm{A} \beta)$ aggregates (amyloid plaques) and the appearance of intracellular aggregates of tau, which are called neurofibrillary tangles. ${ }^{12}$ Altered cholinergic and glutamatergic neurotransmission, apoptosis, oxidative stress, disrupted calcium homeostasis and neuroinflammation have all been implicated in AD pathogenesis. ${ }^{12}$ We will highlight findings of neuroinflammation. In the $A D$ brain, microglia, astrocytes and neurons release various neuroinflammatory mediators, including complement activators and inhibitors, chemokines, cytokines and ROS. ${ }^{13-15}$ Historically, inflammation was thought to be secondary to degeneration. However, compelling evidence suggests that inflammatory mediators might have a significant role in the pathogenesis of the disease. For example, $\mathrm{A} \beta$ metabolism and over-activation of microglia are thought to interact and trigger a vicious cycle leading to neuronal death. Thus, toxic $\mathrm{A} \beta$ peptides are generated by the sequential action of two proteases denoted as $\beta$-secretase and $\gamma$-secretase, which cleave the amyloid precursor protein. $\mathrm{A} \beta$ is toxic to neurons, which in turn activates microglia when they degenerate. ${ }^{15}$ The activated microglia, in turn, are deleterious to neurons. ${ }^{8}$ In addition, toxic $A \beta$ peptides show proinflammatory properties. ${ }^{16}$ The most prominent activation of microglia in $A D$ brain takes place around $A \beta$ deposits. ${ }^{17}$ The stimulated microglia release a wide variety of proinflammatory mediators, including cytokines, complement factors, free radicals, nitric oxide (NO), chemokines (interleukin-18 (IL-18)) and prostanglandins, all of which potentially contribute to further neuronal dysfunction and death. ${ }^{13,18}$ Activated microglia might also stimulate astrocytes that enhance the inflammatory response. These cellular interactions fuel a self-propelling cycle that might drive progressive neurodegeneration in $\mathrm{AD} .{ }^{15}$

Health cost of neurodegenerative disorders associated with a microglia activation component. Neurodegenerative disorders have a tragic impact for those afflicted and their families. In addition, their socioeconomic impact is enormous, when both direct and indirect costs are considered (Table 2). For both $A D$ and PD the number of affected people is predicted to increase dramatically because of the increasing average age of the population. In 2010, 35.6 million people in the world had dementia (around $60 \%$ of

Table 2 Health cost of some neurodegenerative disorders

\begin{tabular}{|c|c|c|c|}
\hline & Year/area & Health costs & References \\
\hline $\begin{array}{l}\text { Dementia ( } 60 \% \text { related to Alzheimer's disease) } \\
\text { Multiple sclerosis } \\
\text { Amyotrophic lateral sclerosis } \\
\text { Parkinson's disease }\end{array}$ & $\begin{array}{ll}\text { - 2010/worldwide } \\
\text { 2005/Europe } \\
\text { - 2010/Germany } \\
\text { - 2007/USA }\end{array}$ & $\begin{array}{ll}\text { - } & 604 \text { billion US } \$ \\
\text { - } & 12.5 \text { billion } € \\
\text { - } & 36380 € / \text { patient } \\
\text { - } & 10.8 \text { billion US } \$\end{array}$ & $\begin{array}{l}\text { Annual World Alzheimer Report }{ }^{116} \\
117 \\
118 \\
119\end{array}$ \\
\hline
\end{tabular}

Direct medical costs as well as the indirect costs (i.e. lost working days for the patients and caregivers) are depicted. 


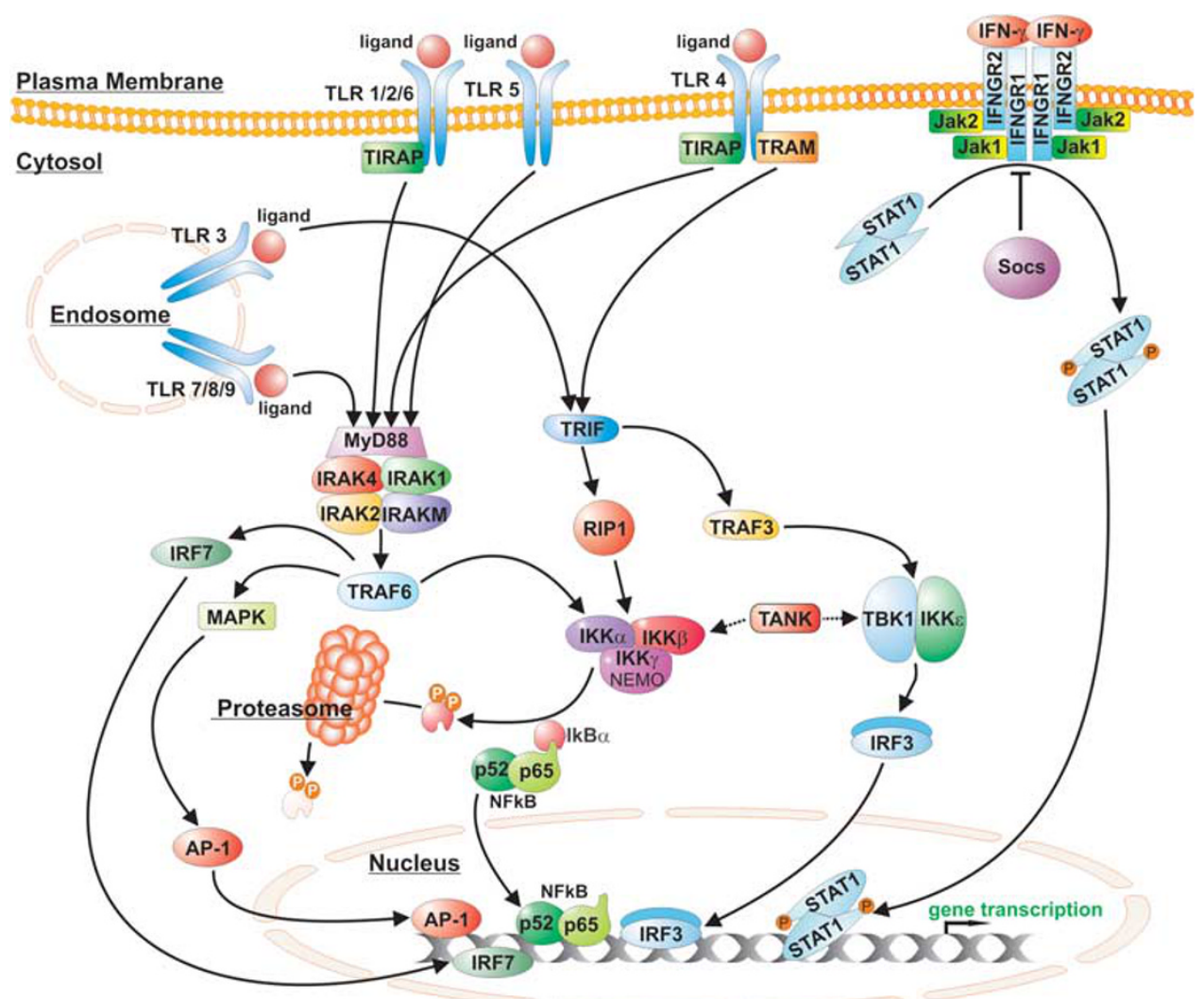

Figure 1 Overview of the TLR-dependent and JAK/STAT-dependent signaling pathways in microglia. TLRs 1, 2, 5, 6, 7, 8 and 9 trigger the classical myeloid differentiation primary response gene (88) (MyD88)-dependent signaling pathway. TLR3 triggers an alternative MyD88-independent, TIR-domain-containing, adapter-inducing IFN- $\beta$ (TRIF)-dependent pathway through the TRIF. TLR4 triggers both the MyD88-dependent pathway through TIR domain-containing adaptor protein (TIRAP)-MyD88 interaction and the MyD88-independent pathway through TRIF-related adapter molecule (TRAM)-TRIF interaction. The MyD88-dependent pathway results in the activation of NF- $\kappa B$, mitogen-activated protein kinase (MAPK) or IRF7 downstream signaling pathways (the latest upon TLR9 activation) through the IL receptor-associated kinase (IRAK) complex (which includes four subunits: two kinases, IRAK-1 and 4, and two non-catalytic units, IRAK-2 and M) and the TNF receptor-associated factor-6 (TRAF6). The MyD88independent pathway results in the activation of IRF3 through the use of two kinases (IKB kinase- $\varepsilon$ (IKK $\varepsilon$ ) and TANK-binding kinase-1 (TBK1)). The TRAF family member-associated NF- $\kappa$ B activator (TANK) interacts with NF- $\kappa$ B essential modulator (NEMO), TBK1 and IKK $\beta$, and may therefore bridge the MyD88-dependent and MyD88-independent pathways. The ligation of the IFN- $\gamma$ receptor (IFNGR) with IFN- $\gamma$ leads to the activation of Jak1and Jak2. STAT1 is phosphorylated by Jak kinases and translocates to the nucleus. Socs counteract STAT1 activation

which will be due to $A D)$. It is estimated that this number will increase to 65.7 million by 2030 and 115.4 million by 2050 .

\section{Microglia Plead Guilty to Neuron Death: Triggers of Microglia-Mediated Neurotoxicity}

Microglia are guilty of causing neuron death. The underlying molecular mechanisms of neurotoxicity are clearly multiple (Figure 1). In the present section we review each one of them briefly.

Proinflammatory cytokines. Immunomodulators referred to as cytokines are particularly important in the genesis of inflammation. Proinflammatory, immunomodulatory and antiinflammatory cytokines include IL- $1 \beta$, tumor necrosis factor- $\alpha$ (TNF- $\alpha$ ), IL-6, IL-8, IL-12, IL-15 and IL-10. ${ }^{19}$ The main proinflammatory cytokines are IL- $1 \beta$ and TNF- $\alpha$. Infusions of LPS into the CNS activate Toll-like receptors (TLRs) on glial cells and induce the activation of microglia. ${ }^{20}$ Through this process, LPS stimulates the expression of multiple cytokines, including IL-1, IL-6 and IL-12; cyclooxygenase-2 (COX-2) and TNF- $\alpha{ }^{21}$ Release of these cytokines creates an environment, which promotes neuronal cell death. ${ }^{7}$ Cytokines including IL- $1 \beta$, interferon- $\gamma(\mathrm{IFN}-\gamma)$ and TNF- $\alpha$ are elevated in postmortem PD brains. ${ }^{22} \mathrm{~A}$ recent metaanalysis study reported significantly higher concentrations of the proinflammatory cytokines IL- 6 , TNF- $\alpha, \mathrm{IL}-1 \beta, \mathrm{IL}-12$ and IL-18 in the peripheral blood of AD subjects as compared with controls. ${ }^{23}$ Therefore, these molecules might be actively involved in disease progression in both $P D$ and $A D$.

Oxidative stress. Oxidative stress generated by reactive microglia is supposed to be the most critical factor in inducing the death of neuronal populations. ${ }^{13}$ It is highly relevant for the pathogenesis of PD as nigral dopamine neurons are highly vulnerable to oxidative stress. ${ }^{2}$ Activated microglia upregulate different enzymes involved in the inflammatory processes mediated by oxidative stress, including inducible NO synthase (iNOS), NADPH oxidase, COX-2 and myeloperoxidase. ${ }^{8}$ Direct evidence supporting a neurotoxic role of microglial NADPH activity and NOS-derived NO is supported by studies using intra-parenchymal LPS 
injections. Thus, NADPH-deficient mice ${ }^{24}$ or pharmacological inhibition of NOS confers protection in the LPS model. ${ }^{25}$

Proteases. MMPs are primarily produced and secreted by inflammatory cells. In particular MMP9 is known to significantly digest the basement membrane and negatively impact on barrier integrity. ${ }^{26}$ MMP9 exerts also direct neurotoxicity. ${ }^{26}$ MMPs are thought to have deleterious roles in different brain diseases, including stroke, multiple sclerosis (MS), infection, AD and PD. ${ }^{26}$

\section{Contract the Killers: Possible Underlying Mechanisms for Microglia Activation}

Microglia are activated in response to neuronal damage, protein aggregate formation and several environmental stimuli/toxins.

Neuronal damage. Microglial activation in response to neurodegeneration or neuron injury was initially perceived as a transient event. ${ }^{27}$ However, increasing evidences indicate that microglia can become chronically activated in response to dying/damaged neurons, causing a selfpropelling cycle of neuron death, which is a proposed mechanism of chronic neuronal loss across diverse neurodegenerative diseases. ${ }^{6,13}$ Thus, damaged DA neurons release several factors that seem to activate microglia, such as MMP3, $\alpha$-synuclein, neuromelanin and $\mu$-calpain. ${ }^{8}$

Protein aggregates. Protein aggregates have been found to induce neuroinflammation in $A D$ and $P D$. In $A D$, in vitro experimental evidence indicates that protofibrils and oligomers of $\mathrm{A} \beta 1-40$ and $\mathrm{A} \beta 1-42$ activate microglia by binding to different receptors such as advanced glycation end products (RAGEs), ${ }^{28}$ CD14, TLR2 and TLR4, ${ }^{29}$ and through heterodimer formation of TLR4 and TLR6, a process dependent on the binding of $\mathrm{A} \beta$ to the CD36 scavenger receptor. ${ }^{30}$ Further evidence demonstrating a link between $\mathrm{A} \beta$ and neuroinflammation comes from studies performed in transgenic animals showing that cerebral amyloid deposition is increased under inflammatory conditions. ${ }^{15}$ As mentioned above, $\alpha$-synuclein appears to have a pivotal role in the pathogenesis of PD. For example, $\alpha$-synuclein is the major protein component of Lewy bodies. ${ }^{31}$ Early observations showing that $\alpha$-synuclein in the $\mathrm{SN}$ are often surrounded by activated microglia suggested that the aggregates activated microglia. ${ }^{5}$ In a transgenic mouse model expressing mutant human $\alpha$-synuclein, proinflammatory molecules are increased and microglia are activated before SN neurons begin to die. ${ }^{32}$ Interestingly neuroinflammation and protein aggregation may be part of the same self-perpetuating vicious cycle, because intra-nigral injections of LPS induce the formation of intra-neuronal $\alpha$-synuclein aggregates in mice overexpressing $\alpha$-synuclein. ${ }^{33}$ Aggregated $\alpha$-synuclein activated microglia, leading to enhanced DA neurotoxicity. Microglial phagocytosis of $\alpha$-synuclein and activation of $\mathrm{NADPH}$ oxidase appeared to be pivotal to the process.
Environmental factors. Different environmental factors, including toxins, and pollutants, may influence inflammatory responses that contribute to the etiology of neurodegenerative diseases. Several lines of evidence indicate that environment is a source for compounds that are both directly toxic to neurons and deleterious through direct stimulation of microglia (reviewed by Glass et al. ${ }^{14}$ ).

Other factors. Traumatic brain injury activates both microglia and astrocytes, and could potentially induce selfsustaining inflammatory responses in the brain. ${ }^{34}$ Accumulating evidence implicates traumatic brain injury as a possible factor predisposing to $\mathrm{AD} .{ }^{34}$ Activation of microglia cells upon systemic infection might also be involved in the early stages of $A D$ pathogenesis. ${ }^{35}$ Recently, a strong correlation between type-2 diabetes and $A D$ was identified, with hyper-insulinemia increasing the risk of $A D .{ }^{14}$ Different mechanisms may explain this correlation. Type-2 diabetes is mostly associated with obesity, which courses with a lowgrade but chronic form of inflammation in adipose tissue, liver and other organs. Recent evidence suggests that systemic inflammation contributes to the exacerbation of acute symptoms of chronic neurodegenerative diseases, including $A D$ and $P D$, and may accelerate disease progression, ${ }^{35} \mathrm{a}$ plausible rationale to explain the correlation between type-2 diabetes and AD.

Once triggered by the factors described above, several intracellular signaling pathways contribute to microglial activation and can be said to sign the 'contract' for the killers (Figure 2).

Pattern-recognition receptors. The first paper that implicated TLRs in host immunity was by Lemaitre et al. in 1996. They observed that Toll-deficient Drosophila are vulnerable to certain fungal infections. ${ }^{36}$ TLRs are a family of pattern-recognition receptors in the innate immune system. They are transmembrane proteins, each with an ectodomain with leucine-rich repeats (LRRs) and a cytoplasmic Toll-IL-1 receptor (TIR) motif homologous to that of IL-1 receptor (IL-1R). ${ }^{37}$ There are 10 functional TLRs (from TLR1 to TLR10) identified in humans and 11 (from TLR1 to TLR7, TLR9 and from TLR11 to TLR13) in mice. ${ }^{37}$ Microglia express TLRs $1-9 .{ }^{38}$ TLRs can bind to highly conserved structural motifs, so called pathogenassociated molecular patterns (PAMPs), ${ }^{39}$ as well as to several host-derived ligands, for instance, heat-shock proteins (HSP), mRNA, high-mobility group box-1 protein, surfactant proteins $A$ and $D$, hyaluronan and fibrinogen). ${ }^{39}$ All these host-derived ligands can be released during tissue damage in the CNS and they are collectively named dangerassociated molecular patterns or DAMPS. Thereby tissue damage due to CNS disease can boost the inflammatory response by activating TLRs, and consequently might further promote cell death. Upon ligand binding, TLRs dimerize and undergo conformational changes that induce a complex cascade of intracellular signaling events, ultimately resulting in the activation of the transcription factors NF- $\kappa \mathrm{B}$ (nuclear factor $\kappa$-light-chain enhancer of activated B cells), activator protein-1 (AP-1), and IFN-regulatory factor-3 (IRF3) and 


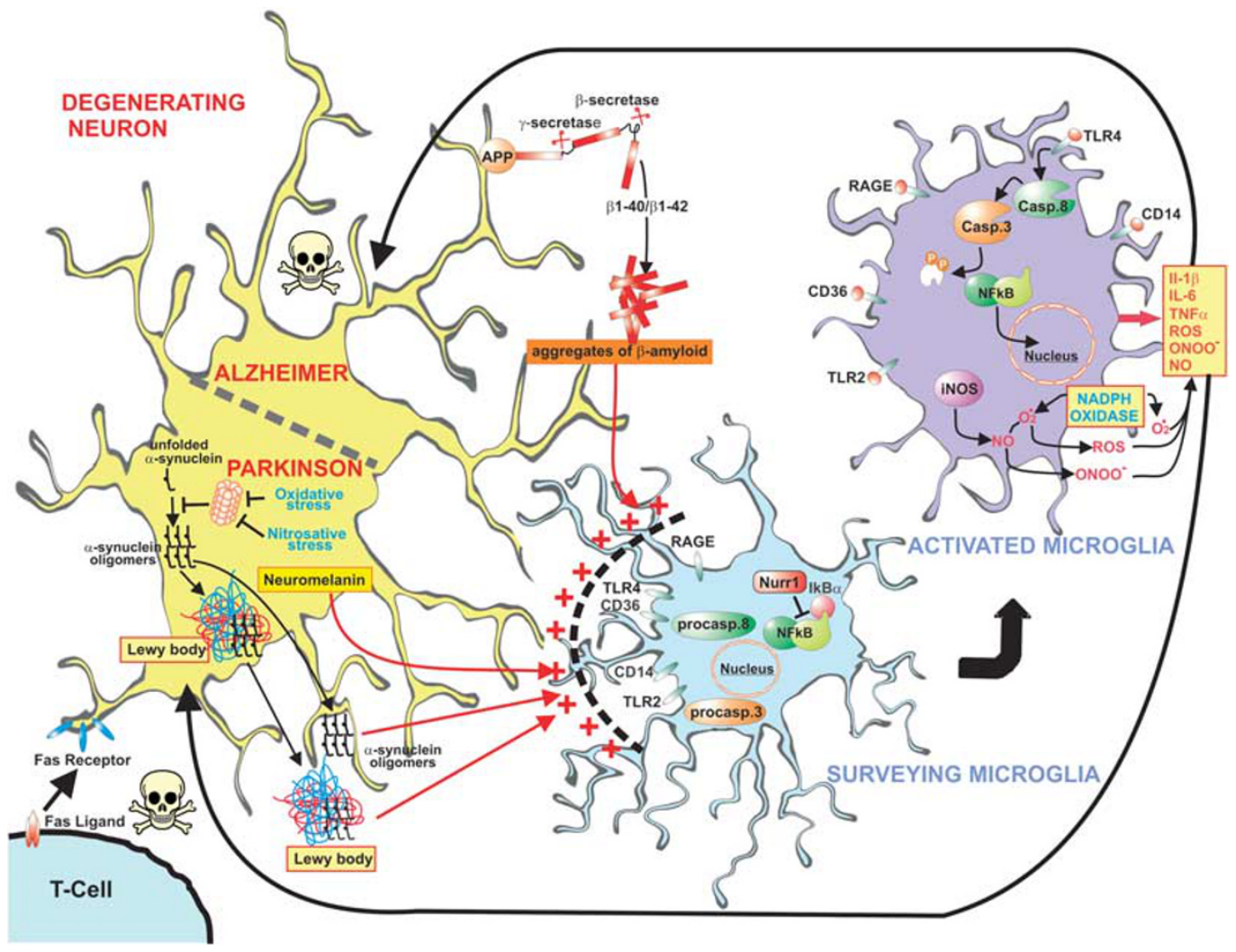

Figure 2 Mechanisms of cell death in $\mathrm{AD}$ and $\mathrm{PD}$ involving inflammation. A degenerating neuron shows key neuropathological features of $\mathrm{PD}$ (left side of the neuron) and $\mathrm{AD}$ (right side of the neuron). Unfolded $\alpha$-synuclein and proteasomal dysfunction induce the formation of oligomers of $\alpha$-synuclein, the main component of Lewy bodies, which are the most distinctive histopathological feature of PD. In AD, sequential action of $\beta$-secretase and $\gamma$-secretase gives rise to the formation of toxic $\mathrm{A} \beta$ (mainly $\mathrm{A} \beta_{1-40}$ and $\mathrm{A} \beta_{1-42}$ ) from the amyloid- $\beta$ precursor protein (APP). These peptides are proinflammatory and their extraneuronal accumulation form amyloid plaques, a typical histopathological feature of $A D$. The presence of oxidative stress in PD and other factors in AD commit neurons to die. Degenerating DA neurons in PD release different proinflammatory factors, including $\alpha$-synuclein and neuromelanin. All these factors are recognized by different pattern-recognition receptors, including TLRs 2 and 4 , CD14, $\mathrm{CD} 36$ and RAGE. Binding to these receptors induces the activation of transcription factors such as NF- $\kappa$ B and AP-1 (not shown) leading to microglia activation. Nurr-1 is a repressor of NF- $\kappa$ B, whereas active caspase-3 is an activator. Activation of microglia release different proinflammatory cytokines and activate ROS-producing enzymes such as iNOS, NADPH oxidase and myeloperoxidase (not shown). NADPH oxidase is a major source of extracellular ROS in response to diverse stimuli. It is a membrane-bound enzyme that catalyzes the production of superoxide anion $\left(\mathrm{O}_{2}^{-}\right)$from oxygen and it is strongly induced in response to different proinflammatory stimuli. $\mathrm{O}_{2}^{-}$easily reacts with NO (mainly derived for upregulation of iNOS by reactive microglia) to produce peroxynitrite, the most reactive free radical, thus inducing nitrosative stress. Peroxynitrite has the potential to both initiate and sustain an autotoxic loop considered as a neuronal damaging mechanism in neurodegenerative diseases. Over-activation of microglia is deleterious to neurons, thus enhancing neuronal cell death, which in turn release more proinflammatory factors thus establishing a self-perpetuating process of neuroinflammation and neurodegeneration

IRF7. These factors, in turn, regulate the expression of a wide array of genes involved in inflammatory responses.

MyD88-dependent and -independent pathways. Activation of most TLRs mostly results in the recruitment of the adaptor protein myeloid differentiation factor-88 (MyD88) (see Figure 2 for further details), finally leading to the nuclear translocation of $\mathrm{NF}-\kappa \mathrm{B}^{39}$ In addition, there is an MyD88independent pathway. ${ }^{39}$

The Jak-STAT signaling pathway. Type-I and II cytokine receptors are a conserved family of $\sim 40$ members that includes the receptors for ILs, IFNs and hormones. ${ }^{40}$ These receptors are associated with a cytoplasmic kinase. These cytoplasmic kinases comprise the four members of the Janus kinase (Jak) family: Jak1, Jak2 and tyrosine kinase-2 (Tyk2) transduce signaling from several receptors, whereas Jak3 does so only for one receptor, the common $\gamma$-chain, or $\gamma \mathrm{c}$.
Upon cytokine binding, the receptor-associated Jaks are activated and in turn phosphorylate the tyrosine residues in the receptor cytoplasmic domain. This event provides a docking site for proteins with Src homology-2 domains, one important class of which is the signal transducer and activator of transcription (Stat) family of transcription factors. With seven members in all (Stat1, Stat2, Stat3, Stat4, Stat5a, Stat5b and Stat6), these DNA-binding proteins provide a rapid membrane-to-nucleus pathway for regulation of gene expression. ${ }^{41}$ After cytokine stimulation, a family of cytokine-induced inhibitors termed suppressors of cytokine signaling (Socs proteins) is rapidly induced. The predominant function of the Socs proteins is to block the generation of the Stat signal from a cytokine receptor. ${ }^{42}$ In canonical IFN- $\gamma$-Jak-STAT1 signaling (reviewed by Stark $^{43}$ ) the binding of IFN- $\gamma$ to its receptor leads to the activation of receptor-associated Jak1 and Jak2, and the phosphorylation of a receptor tyrosine residue working as a docking site for 
STAT1. STAT1 is then activated by phosphorylation and translocates to the nucleus where it stimulates transcription of STAT1 target genes.

Another mechanism for IFN- $\gamma$ to activate macrophages is by enhancing macrophage responsiveness to other inflammatory stimuli, such as TLR ligands and TNF. This mechanism is known by the name 'priming'. By this 'priming' of IFN- $\gamma$, the TLR-dependant expression of several proinflammatory cytokines and chemokines is greatly augmented. ${ }^{44}$ IFN- $\gamma$ suppresses IL-10 production by increasing the activity of glycogen synthase kinase-3 $\beta$ (GSK3 $\beta$ ), a serine/threonine kinase that inhibits the function of AP-1 and CREB, two transcription factors critical for IL-10 expression.

NF- $\kappa$ B: Stress sensor/inflammatory trigger. The NF- $\kappa \mathrm{B}$ signaling pathway has a major role in the development, maintenance and progression of most chronic diseases. $\mathrm{NF}-\kappa \mathrm{B}$ controls the expression of genes involved in immune inflammatory responses, acute-phase inflammatory responses, oxidative stress responses, cell adhesion, differentiation and apoptosis. ${ }^{45}$ Ranjan Sen and David Baltimore first identified NF- $\kappa$ B in 1986. They found that it was bound to an enhancer element of the immunoglobulin $\kappa$-light chain gene in the nucleus of B cells. ${ }^{46}$ It is conserved during evolution and is ubiquitous in nature, that is, present in all cell type. It belongs to the family of Rel proteins that includes c-Rel, RelA (p65), RelB, NF- $\kappa \mathrm{B} 1$ and NF- $\kappa \mathrm{B} 2$, all of which can form hetero- or homodimers. ${ }^{46} \mathrm{NF}-\kappa \mathrm{B}$ proteins are present in the cytoplasm in an inactive form together with inhibitory $\mathrm{I}_{\kappa} \mathrm{B}\left(\mathrm{I}_{\kappa} \mathrm{B} \alpha, \mathrm{I}_{\kappa} \mathrm{B} \beta\right.$ and $\left.\mathrm{I}_{\kappa} \mathrm{B} \varepsilon\right) .{ }^{46} \mathrm{NF}-\kappa \mathrm{B}$ signaling is divided (depending on which proteins are involved) in the canonical (classical) pathway initiated by NF- $\kappa \mathrm{B} 1$ and a noncanonical (alternative) pathway initiated by NF- $\kappa \mathrm{B} 2$.

Whereas the classical pathway depends on the IKK complex consisting of $\mathrm{IKK} \alpha, \mathrm{IKK} \beta$, IKK $\gamma$ and the inhibitory subunit $\mathrm{I}_{\kappa} \mathrm{Bs}$, the alternative pathway depends on $\mathrm{IKK} \alpha$ homodimers and the NF- $\kappa$ B-inducing kinase (NIK). ${ }^{47}$ Once in the nucleus, activated $\mathrm{NF}-\kappa \mathrm{B}$ undergoes a series of post-translational modifications, including phosphorylation, acetylation and methylation. These modifications regulate both the strength and the duration of $\mathrm{NF}-\kappa \mathrm{B}$ activity. ${ }^{48}$ Activated NF- $\kappa \mathrm{B}$ binds to specific DNA sequences in target genes, which are designated as $\kappa \mathrm{B}$ elements, and regulates the transcription of over 500 genes involved, in, for example, immunoregulation.

\section{Astrocytes as Mediators of Inflammation}

Astrocytes, the most abundant cells in the brain, besides having functions in metabolic support, blood-brain barrier integrity, $\mathrm{K}^{+}$buffering and regulation of synaptic levels of glutamate, have the ability to work as immunocompetent cells in the CNS. ${ }^{49}$ Thus, astrocytes express major histocompatibility complex-II (MHC-II) and present antigen to T-cell lines. ${ }^{50}$ In addition, astrocytes express different patternrecognition receptors, including TLRs, and produce a wide array of chemokines and cytokines that act as immune mediators. ${ }^{50}$ More important, selective inactivation of NF- $\kappa \mathrm{B}$ in astrocytes reduced inflammation and cell death in different animal models of neurodegeneration, including spinal cord injury, ${ }^{51}$ and in an animal model of MS. ${ }^{52}$ Keeping this view, it has been reported that $\alpha$-synuclein proteins, whose accumulation is a typical hallmark of PD, released from neuronal cells are readily endocytosed by astrocytes and trigger immune responses. ${ }^{53}$ When the internalized $\alpha$-synuclein accumulates in astrocytes, the cells produce glial inclusions and inflammatory responses. ${ }^{53}$ In $A D$, astroglial activation is primarily triggered by amyloid deposits in the extracellular space and AGE-modified proteins thus inducing the production of a variety of proinflammatory factors to be released from astrocytes. $^{49}$ Several cytokines, including IL-1 $\beta$ and IL-6, have been implicated in the induction and modulation of reactive astrogliosis and pathological inflammatory responses, ${ }^{50}$ a demonstration that a crosstalk between microglia and astrocytes activation seems to contribute to the inflammatory responses in the brain. Gage et al. ${ }^{54}$ have demonstrated in primary cell cultures that LPS-induced expression of factors such as IL-1 $\beta$ and TNF- $\alpha$ by microglia results in a paracrine activation of astrocytes, with the subsequent production of toxic mediators by astrocytes, including $\mathrm{NO}$ and ROS. These factors are suggested to act additively or synergistically with neurotoxic factors produced by microglia. The detailed molecular mechanisms involved in this crosstalk are emerging and some of the first important signaling pathways (e.g. nuclear receptor related-1 protein-1 (Nurr1)/REST co-repressor (CoREST $\left.{ }^{54}\right)$ ) were described recently. Consequently, under pathological conditions, such as those seen in chronic inflammation and neurodegeneration, it has been proposed that astroglia switch from metabolic support cells to immunological cells capable of inducing inflammation through the production of a variety of proinflammatory factors. ${ }^{49}$

\section{Caspases, the Usual Suspects: Emerging Non-Apoptotic Role for Killer Caspases}

Proinflammatory caspase-1 and the inflammasomes. Caspases, a family of cysteine proteases, were discovered almost two decades ago. In 1992, two laboratories simultaneously identified IL-1 $\beta$-converting enzyme (ICE), which is involved in the generation of active IL-1 $\beta$. It was later referred to as caspase- 1 being the first mammalian caspase characterized. ${ }^{55,56}$ Caspase-1 together with caspase-11 and caspase-12 in mouse. and caspase-4 and caspase-5 in human, comprises the proinflammatory caspases. ${ }^{57}$ Caspase- 1 catalytic activity is tightly regulated by signal-dependent auto-activation within multi-protein complexes called 'inflammasomes' that mediate caspase-1 autocatalytic activation and the subsequent cleavage of the inactive precursors of $\mathrm{IL}-1 \beta$ and $\mathrm{IL}-18$ into bioactive cytokines. $^{58}$ For a review of the different inflammasomes, which are, NLR family pyrin domain containing-1 (NLRP1), NLRP3, IPAF and AIM2 (absent in melanoma-2) inflammasomes, see reference Schroder and Tschopp. ${ }^{58}$ Importantly, strong associations between dysregulated inflammasome activity, by extension caspase-1 activity, and human inflammatory diseases highlight the importance of this signaling pathway in tailoring the innate immune response. Indeed, the significance of the inflammasome for the initiation of the inflammatory response during systemic 
diseases has already been shown, and members of the inflammasome complex were found to be induced in acute brain injury. However, the specific pathophysiological role of the inflammasome in neurodegenerative disorders still remains to be clarified (for a review see reference Trendelenburg ${ }^{59}$ ). Interestingly, recently it was found that $\mathrm{A} \beta$ fibrils can activate NALP3 inflammasomes through the lysosomal damage in mouse microglia ${ }^{60}$ and proposed to contribute to $A D$ pathology. ${ }^{61}$

Apoptotic caspases executioners of cell death. To date, the mammalian genome encodes 14 caspases, seven of which function in programmed cell death/apoptosis and will henceforth be termed apoptotic caspases, or simply killer caspases. During apoptosis, activated killer caspases cleave selected target proteins to execute cell death. ${ }^{62}$ The apoptotic caspases comprise two distinct classes: The upstream initiator caspases, which include caspases 2, 8, 9 and 10, and the downstream effecter caspases, which include caspases-3, 6 and 7. Effecter caspases cleave a wide range of distinct proteins substrates in different cellular compartments and are responsible for many of the changes typical of apoptosis. They are expressed as zymogens, and are activated when cleaved by the initiator caspases. Initiators caspases are also expressed as zymogens but are activated by recruitment into large multi-protein complexes. Well-defined apoptotic caspase activating complexes include the apoptosome (activating caspase-9), the piddosome (activating caspase-2) and the death-inducing signaling complex (DISC, activating caspases 8 and 10). ${ }^{63}$ Two major caspase-dependent pathways of apoptosis signaling have been described, which trigger cell death either by activation of death receptors at the cell surface (i.e. extrinsic pathway) or through the disruption of the outer mitochondrial membrane barrier function, with the simultaneous release of proapoptotic molecules from the mitochondria into the cytosol (i.e., intrinsic pathway). ${ }^{64}$

Non-apoptotic roles for killer caspases. Even if killer caspases can been seen as 'the usual suspect' in the death of cells, the opinion that the so-called 'apoptotic caspases' are more than just killers is supported by several recent studies (Table 3). Miossec et al., ${ }^{65}$ as early as 1997, reported that T-lymphocytes upon stimulation acquire caspase-3 activation without evidence of ongoing apoptosis. Shortly thereafter, inhibition of caspase activation was reported to prevent T-cell proliferation. ${ }^{66}$ Finally, in vivo observations corroborated these initial findings by convincingly proving evidence that the initiator caspase- 8 is indispensable for T-cell activation and proliferation. ${ }^{67}$ Admittedly, anucleate cell types, namely keratinocytes, ${ }^{68}$ lens fiber cells ${ }^{69}$ and erythroid cells, ${ }^{70}$ are known to require effecter caspases such as caspase-3 for the removal of their nucleus, as part of their terminal differentiation. Likewise, nucleate cells, including skeletal muscle cells, ${ }^{71}$ osteoblasts, ${ }^{72}$ B cells ${ }^{73}$ and myelomonocytic cells, ${ }^{74}$ are known to employ the effecter caspase 3 or 6 for their differentiation. Furthermore, initiator caspases such as caspase-8 and caspase- 9 are not always involved in cell death signaling. For example, activation of the apical caspase-9, during myoblastic differentiation, in turn leads to caspase-3 activation, which contributes to myotube formation. ${ }^{75}$ Substantial evidence has been built up regarding the non-apoptotic functions of caspase-8, involving embryonic development; ${ }^{74} \mathrm{NF}-\kappa \mathrm{B}$ activation; ${ }^{76}$ cell migration; ${ }^{77}$ proliferation of $\mathrm{T}$ cells, B cells, natural killer cells ${ }^{76}$ and hematopoietic progenitor cells; ${ }^{78}$ and myeloid or lymphoid differentiation patterns. ${ }^{74}$

In the brain, which is the focus of this review, activation of killer caspases can occur in various cell types as part of multiple non-apoptotic, essential cell functions. Active caspase-3 has been found in the non-apoptotic, proliferating and differentiating neuronal cells of the forebrain ventricular zone and the external granular layer of the developing cerebellar cortex. ${ }^{79}$ In neurons, caspases are present in the dendrites, axons and pre- and postsynaptic terminals, and there is evidence that caspases can be activated in dendrites, synaptosomes and growth cones, without inducing cell death. Several studies have implicated apoptotic caspases in the regulation of synaptic plasticity. Long-term synaptic depression and AMPA ( $\alpha$-amino-3-hydroxy-5-methyl-4-isoxazolepropionic acid) receptor internalization in mouse hippocampal neurons requires caspase-9 and caspase-3/7

Table 3 Non-apoptotic roles of apoptotic caspases

\begin{tabular}{|c|c|c|}
\hline Caspases & Non-apoptotic function & References \\
\hline Caspase-3 & $\begin{array}{l}\text { - Upon stimulation, T-lymphocytes activate caspase-3 without evidence of apoptosis } \\
\text { - Removal of nucleus in keratinocytes, lens fiber cells and erythroid cells } \\
\text { - Differentiation of skeletal muscle cells, osteoblasts, B cells, myelomonocytic cells and Bergmann glia cells } \\
\text { - Cong-term synaptic depression and AMPA receptor internalization in hippocampal neuron } \\
\text { - Cytoskeletal remodeling associated with astrogliosis }\end{array}$ & $\begin{array}{l}65 \\
68-70 \\
71-75,82 \\
80,81 \\
83\end{array}$ \\
\hline Caspase-8 & $\begin{array}{l}\text { - Embryonic development } \\
\text { T-cell activation } \\
\text { - } \text { NF- } k \text { B activation } \\
\text { - Cell migration } \\
\text { - } \text { Mifferentiation of myeloid and lymphoid cells } \\
\text { Microglia activation }\end{array}$ & $\begin{array}{l}74 \\
67,120 \\
67,76,78,120 \\
76 \\
77 \\
74 \\
21\end{array}$ \\
\hline Caspase-9 & $\begin{array}{l}\text { - Differentiation of skeletal muscle cells } \\
\text { - Long-term synaptic depression and AMPA receptor internalization in hippocampal neuron }\end{array}$ & $\begin{array}{l}75 \\
80\end{array}$ \\
\hline
\end{tabular}

Abbreviations: AMPA receptor, $\alpha$-amino-3-hydroxy-5-methyl-4-isoxazolepropionic acid receptor; NF- $\kappa$ B, nuclear factor $\kappa$-light-chain enhancer of activated B cells. 


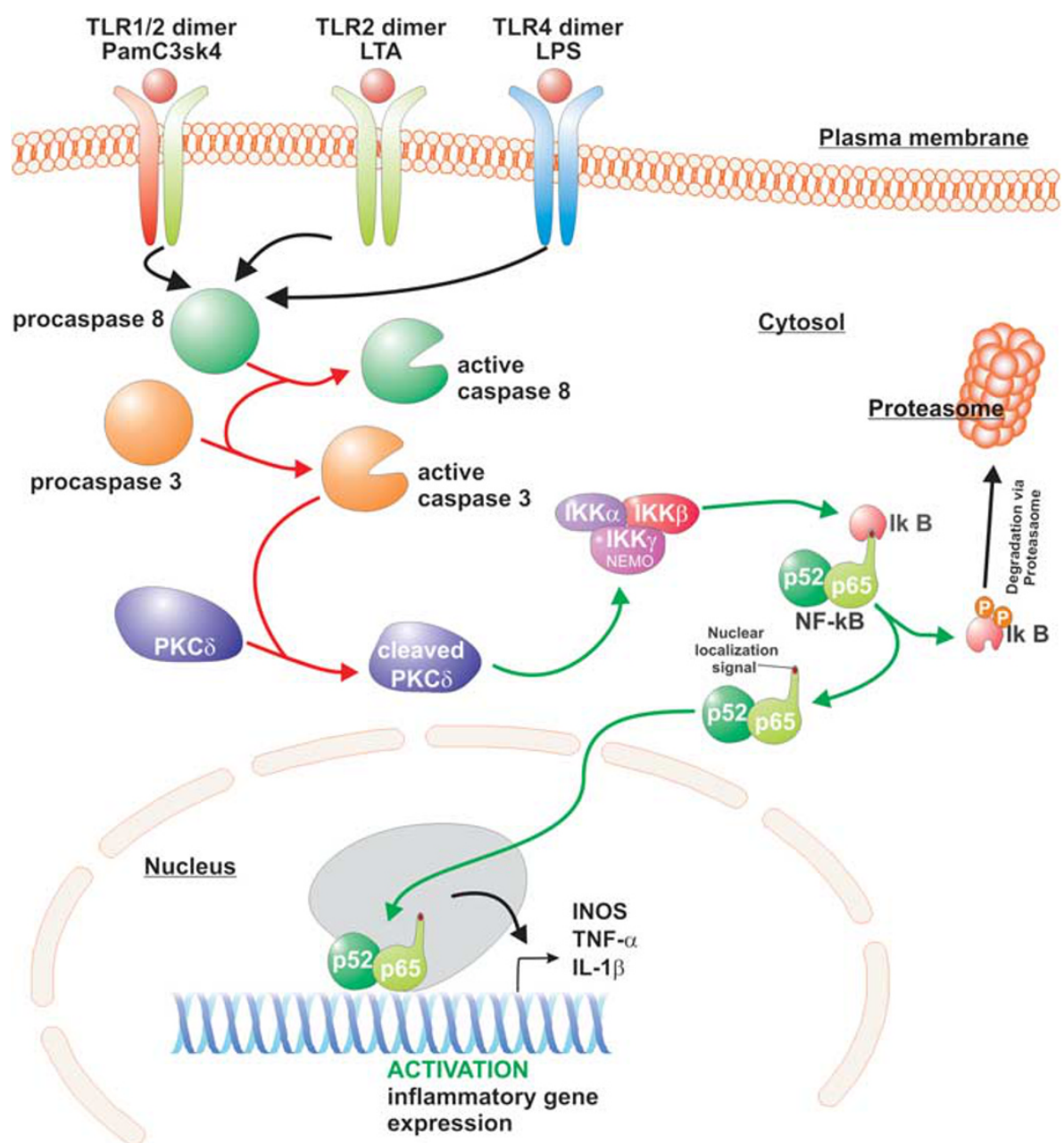

Figure 3 Apoptotic caspases control microglia activation. Activation of TLRs with lipoteichoic acid (LTA, TLR2 agonist), PamC3sk4 (synthetic lipopeptide TLR1/2 agonist) or LPS (TLR4 agonist) leads to the orderly activation of caspase- 8 and caspase-3. Caspase- 3 activates the NF- $\kappa$ B pathways through processing and activation of PKC $\delta$. Nuclear accumulation of NF- $\kappa \mathrm{B}$ leads to the transcriptional activation of inflammatory gene expression

activity. ${ }^{80}$ Caspase-3 cleaves and activates calcineurin, which in turn triggers the dephosphorylation and removal of the GluR1 subunit of the AMPA-type receptor from postsynaptic sites. This caspase-3-dependent mechanism is suggested to promote early synaptic dysfunction in a mouse model of $\mathrm{AD}$ at the onset of memory decline. ${ }^{81}$ Activation of caspase-3 in the postnatal cerebellum has also been linked to Bergmann glia differentiation. ${ }^{82}$ In astroglia, activation of this enzyme, in response to excitotoxic brain damage, is suggested to have role in the cytoskeletal remodeling associated with astrogliosis. $^{83}$

\section{License to Kill: Caspases Control Microglia Activation}

We recently described an unexpected novel function for caspases in the control of microglia activation and thereby neurotoxicity $^{21}$ (Figure 3). We showed that orderly activation of caspase- 8 and caspase- 3 regulates microglia activation through a protein kinase- $\mathrm{C} \delta$ ( $\mathrm{PKC} \delta$ )-dependent pathway. Activation of microglia and inflammation-mediated neurotoxicity are believed to have important roles in the pathogenesis of several neurodegenerative disorders. In our study, we found that stimulation of microglia with various inflammogens activates caspase- 8 and caspase- $3 / 7$ in absence of cell death in vitro and in vivo. Knockdown or chemical inhibition of these caspases hindered microglia activation and importantly reduced neurotoxicity. We also observed that these caspases are activated in microglia in the SN in PD subjects and in the frontal cortex of AD subjects. This novel view of the molecular mechanisms underlying the activation of microglia opens up avenues for new pharmacological interventions aimed at mitigating brain inflammation and subsequent cell death. Such novel strategies might lead to new treatments for neurological disorders where neuroinflammation has a role, such $A D, P D$, amyotrophic lateral sclerosis (ALS) and MS.

\section{Under Arrest: Microglial Caspases are Potential Targets for Future Neuroprotective Strategies}

Neuronal cell death is a major feature of many chronic neurodegenerative diseases, such as AD, PD, ALS and Huntington's disease (HD), as well as acute damage following 
OPEN QUESTIONS:

- It is unclear whether inhibition of caspase activation specifically in microglia contributes to the neuroprotective effects of caspase inhibitors. Could caspase inhibition be neuroprotective by targeting the microglia rather than the neurons themselves?

- It is also unclear whether the newly described caspasedependent signaling pathway controlling microglia activation could also contribute to the beneficial effects of activated microglia.

- Could the selective inhibition of certain caspases in active microglia be a possible therapy to decrease the demise under several neuroinflammatory conditions such as Parkinson's and Alzheimer's diseases?

stroke, spinal cord injury and brain trauma. While effective neuroprotective therapies are still lacking, the most common therapeutic strategies for those brain disorders aim at rescuing the neurons. As caspase activation is considered a feature of apoptosis, synthetic caspase inhibitors have been developed both as research tools, and with the hope that they may eventually be used to prevent cell death in the clinic. Caspase inhibitors have been reported to successfully exert neuroprotective effects in a number of animal models for neurodegenerative disorders, including $\mathrm{AD},{ }^{84} \mathrm{HD},{ }^{85} \mathrm{PD},{ }^{86}$ ALS, ${ }^{87}$ as well as acute neurologic diseases, including ischemia, stroke or traumatic injury. ${ }^{88,89}$ However, one should also keep in mind these neurodegenerative diseases are also characterized by reactive microgliosis, ${ }^{8,90}$ and that our recent study now links apoptotic caspases to the control of microglia activation. ${ }^{21}$ Presently, it is unclear whether inhibition of caspase activation specifically in microglia contributes to the neuroprotective effects of caspase inhibitors (Box 2, OPEN QUESTIONS). Therapies that will effectively target microglia activation and thereby their neurotoxicity could significantly improve the therapeutic outcome of these brain diseases. In conclusion, we propose that interfering with caspases that contribute to the activation of microglial can reduce neuronal cells loss.

\section{Current caspase inhibitors, opportunities and} limitations. The next question is which caspase inhibitors are available and might be suitable to target and control microglia activation? We recently reported that intra-nigral administration of fluoromethyl ketone (fmk)-derivative tetrapeptide caspase inhibitors - DEVD-fmk targeting caspase-3/7 or IETD-fmk targeting caspase-8 - hindered in vivo microglia activation. ${ }^{21}$ The required administration mode for these caspase inhibitors certainly limits their use in a clinical setting. Furthermore, fmk metabolizes in the liver to form fluoroacetate, an extremely toxic poison. ${ }^{91}$

Quinolyl-valyl-O-methylaspartyl-[-2,6-difluorophenoxy]methylketone (Q-VD-OPh) is a newer, third-generation broadspectrum caspase inhibitor that has potential as a therapeutic compound. ${ }^{92}$ Most importantly, Q-VD-OPh crosses the blood-brain barrier and appears to be far superior to Z-VAD in many respects, including greater potency, selectivity, stability and cell permeability. ${ }^{92}$ After acute treatment of mice with Q-VD-OPh, all organs were normal suggesting a lack of toxicity. ${ }^{92}$ Evidence for neuroprotection included studies demonstrating efficacy of Q-VD-OPh in animal models of
$A D, P D, H D$, spinal cord injury and stroke. ${ }^{84,88,93,94}$ It remains to be established whether Q-VD-OPh affects microglia activation in those disease models and contributes to the neuroprotective effect in that manner.

Finally, minocycline is particularly interesting in the context of this review. It is a second-generation tetracycline that effectively crosses the blood-brain barrier and shows remarkably broad neuroprotective properties. Indeed, neuroprotection by minocycline has been observed in various animal models of PD, HD, ALS, MS, cerebral ischemia, spinal cord injury and traumatic brain injury. ${ }^{85,95,96}$ The precise mechanism of minocycline's neuroprotective effects remains unclear. It is known, however, that minocycline is a potent inhibitor of caspase-related apoptotic pathways. ${ }^{95}$ Minocycline has been shown to block the activation and proliferation of microglia in an animal model of global brain ischemia, PD and $A D .^{90,95}$ Minocycline not only prevents the activation of microglia, but also the upregulation of caspase-1 and the formation of mature IL- $1 \beta$; the activation of NADPH-oxidase and iNOS; and the release of NO metabolites, all of which are key microglial-derived cytotoxic mediators. ${ }^{90}$ Thus, minocycline is a potent inhibitor of both caspase activation and microglial activation. However, the link between both awaits further studies. Minocycline shows high bioavailability after oral administration, crosses the blood-brain barrier and has a proven track record for safety in a number of clinical trials involving humans. It is being evaluated in clinical trials in patients with HD, PD, MS and ALS, and for spinal cord injury. A phase-III trial involving minocycline for treatment of ALS was completed recently. Unfortunately, the results of the trial were negative as the patients on minocycline declined more quickly than those on placebo. ${ }^{97}$ These results are disappointing and certainly will probably have negative implications for potential future clinical trials with minocycline. ${ }^{98}$ In addition, a phase-II trial for PD indicated a decreased tolerability of minocycline in the treatment group. ${ }^{99}$ At last, the results of a futility phase-II study on HD with minocycline indicated that further trials with minocycline in HD are not warranted. ${ }^{100}$

\section{Perspectives}

We have summarized the key aspects of neuroinflammation and its obvious involvement in the etiopathogenesis of different neurodegenerative diseases. The discovery that apoptotic/killer caspases regulate microglia activation and neurotoxicity will open up avenues for new therapeutic strategies, aimed at mitigating neuroinflammation in neurodegeneration. Brain inflammation is typically divided into three phases (acute, chronic and resolution), in which the microglia are largely in three different morphologies (surveying, activated and amoeboid/phagocytic). Considering the presumed dual role of microglia (both beneficial and detrimental), it will be necessary to fully characterize first the role of apoptotic caspases in each activation phase of microglia. Different animal models of neurodegeneration (acute versus chronic inflammation) should help to shed further light on this issue.

We speculate that inhibition of apoptotic/killer caspases might be a viable approach to therapeutic intervention. As mentioned earlier, however, an increasing number of studies 
demonstrate that these proteases have important roles in a multitude of physiological conditions. Thus, inhibiting caspases might conceivably inhibit functions that are essential for normal neuronal activity and thereby would preclude the use of such an approach. The disappointing results of minocycline in clinical trials of different neurodegenerative diseases might be taken to suggest that it is important to develop inhibitors, which are selective for microglial caspases. Thus a major challenge will be to develop tools allowing the inhibition of specific caspases in selective cell types. Different strategies might be useful for this purpose: (i) A first approach may be suppression of caspase by targeted delivery of small interfering RNA specifically to macrophage/ microglial cells; ${ }^{101}$ and (ii) the development of specific nontoxic nanocarriers able to cross the blood-brain barrier and to safety release caspase inhibitors in those areas showing high microgliosis. ${ }^{102}$ These are great technical challenges, but the new insights into the non-lethal roles of caspases in microglia certainly support that it could be worthwhile and indicate that the idea of inhibiting caspases as a therapy for neurodegenerative diseases is anything but dead.

\section{Conflict of Interest}

The authors declare no conflict of interest.

Acknowledgements. This work has been supported by grants from Spanish Ministerio de Ciencia y Tecnología (SAF2009-13778) and Proyecto de Excelencia from Junta de Andalucia (CTS-6494); the Swedish Research Council; the Parkinson Foundation of Sweden and the Swedish Cancer Society. MAB and $\mathrm{PB}$ are members of the Strong Research Environment Multipark (Multidisciplinary Research in Parkinson's Disease at Lund University).

1. Rio-Hortega Pd. El 'tercer elemento' de los centros nerviosos. Poder fagocitario y movilidad de la microglia. Bol de la Soc espanola de Biol 1919; Ano ix: 154-166.

2. Obeso JA, Rodriguez-Oroz MC, Rodriguez M, Lanciego JL, Artieda J, Gonzalo N et al. Pathophysiology of the basal ganglia in Parkinson's disease. Trends Neurosci 2000; 23 (10 Suppl): S8-19.

3. Mouradian MM. Recent advances in the genetics and pathogenesis of Parkinson disease. Neurology 2002; 58: 179-185.

4. Langston JW, Forno LS, Tetrud J, Reeves AG, Kaplan JA, Karluk D. Evidence of active nerve cell degeneration in the substantia nigra of humans years after 1-methyl-4-phenyl1,2,3,6-tetrahydropyridine exposure. Ann Neurol 1999; 46: 598-605

5. McGeer PL, Itagaki S, McGeer EG. Expression of the histocompatibility glycoprotein HLA-DR in neurological disease. Acta Neuropathol 1988; 76: 550-557.

6. McGeer PL, Schwab C, Parent A, Doudet D. Presence of reactive microglia in monkey substantia nigra years after 1-methyl-4-phenyl-1,2,3,6-tetrahydropyridine administration. Ann Neurol 2003; 54: 599-604.

7. Herrera AJ, Castano A, Venero JL, Cano J, Machado A. The single intranigral injection of LPS as a new model for studying the selective effects of inflammatory reactions on dopaminergic system. Neurobiol Dis 2000; 7: 429-447.

8. Block ML, Zecca L, Hong JS. Microglia-mediated neurotoxicity: uncovering the molecular mechanisms. Nat Rev Neurosci 2007; 8: 57-69.

9. Frank-Cannon TC, Tran T, Ruhn KA, Martinez TN, Hong J, Marvin M et al. Parkin deficiency increases vulnerability to inflammation-related nigral degeneration. $J$ Neurosci 2008; 28: 10825-10834.

10. Brochard V, Combadiere B, Prigent A, Laouar $Y$, Perrin A, Beray-Berthat V et al. Infiltration of CD4+ lymphocytes into the brain contributes to neurodegeneration in a mouse model of Parkinson disease. J Clin Invest 2009; 119: 182-192.

11. Qin L, Wu X, Block ML, Liu Y, Breese GR, Hong JS et al. Systemic LPS causes chronic neuroinflammation and progressive neurodegeneration. Glia 2007; 55: 453-462.

12. Selkoe DJ, Schenk D. Alzheimer's disease: molecular understanding predicts amyloid based therapeutics. Annu Rev Pharmacol Toxicol 2003; 43: 545-584.

13. Block ML, Hong JS. Microglia and inflammation-mediated neurodegeneration: multiple triggers with a common mechanism. Prog Neurobiol 2005; 76: 77-98.

14. Glass CK, Saijo K, Winner B, Marchetto MC, Gage FH. Mechanisms underlying inflammation in neurodegeneration. Cell 2010; 140: 918-934.
15. Heneka MT, O'Banion MK, Terwel D, Kummer MP. Neuroinflammatory processes in Alzheimer's disease. J Neural Transm 2010; 117: 919-947.

16. Sasaki A, Yamaguchi H, Ogawa A, Sugihara S, Nakazato Y. Microglial activation in early stages of amyloid beta protein deposition. Acta Neuropathol 1997; 94: 316-322.

17. Akiyama $\mathrm{H}$, Arai $\mathrm{T}$, Kondo $\mathrm{H}$, Tanno $\mathrm{E}$, Haga $\mathrm{C}$, Ikeda K. Cell mediators of inflammation in the Alzheimer disease brain. Alzheimer Dis Assoc Disord 2000; 14(Suppl 1): S47-S53.

18. Amor S, Puentes F, Baker D, van der Valk P. Inflammation in neurodegenerative diseases. Immunology 2010; 129: 154-169.

19. Park KM, Bowers WJ. Tumor necrosis factor-alpha mediated signaling in neuronal homeostasis and dysfunction. Cell Signal 2010; 22: 977-983.

20. Lehnardt S, Lachance C, Patrizi S, Lefebvre S, Follett PL, Jensen FE et al. The toll-like receptor TLR4 is necessary for lipopolysaccharide-induced oligodendrocyte injury in the CNS. J Neurosci 2002; 22: 2478-2486.

21. Burguillos MA, Deierborg T, Kavanagh E, Persson A, Haiji N, Garcia-Quintanilla A et al. Caspase signalling controls microglia activation and neurotoxicity. Nature 2011; 472 : 319-324.

22. Mogi M, Harada M, Narabayashi $H$, Inagaki H, Minami M, Nagatsu T. Interleukin (IL)-1 beta, IL-2, IL-4, IL-6 and transforming growth factor-alpha levels are elevated in ventricular cerebrospinal fluid in juvenile parkinsonism and Parkinson's disease. Neurosci Lett 1996; 211: 13-16.

23. Swardfager W, Lanctot K, Rothenburg L, Wong A, Cappell J, Herrmann N. A metaanalysis of cytokines in Alzheimer's disease. Biol Psychiatry 2010; 68: 930-941.

24. Qin L, Liu Y, Wang T, Wei SJ, Block ML, Wilson B et al. NADPH oxidase mediates lipopolysaccharide-induced neurotoxicity and proinflammatory gene expression in activated microglia. J Biol Chem 2004; 279: 1415-1421.

25. Arimoto T, Bing G. Upregulation of inducible nitric oxide synthase in the substantia nigra by lipopolysaccharide causes microglial activation and neurodegeneration. Neurobiol Dis 2003; 12: 35-45.

26. Rosenberg GA. Matrix metalloproteinases and their multiple roles in neurodegenerative diseases. Lancet Neurol 2009; 8: 205-216.

27. Streit WJ, Walter SA, Pennell NA. Reactive microgliosis. Prog Neurobiol 1999; 57 : 563-581.

28. Yan SD, Stern D, Kane MD, Kuo YM, Lampert HC, Roher AE. RAGE-Abeta interactions in the pathophysiology of Alzheimer's disease. Restor Neurol Neurosci 1998; 12: 167-173.

29. Jana M, Palencia CA, Pahan K. Fibrillar amyloid-beta peptides activate microglia via TLR2: implications for Alzheimer's disease. J Immunol 2008; 181: 7254-7262.

30. Stewart CR, Stuart LM, Wilkinson K, van Gils JM, Deng J, Halle A et al. CD36 ligands promote sterile inflammation through assembly of a Toll-like receptor 4 and 6 heterodimer. Nat Immunol 2010; 11: 155-161.

31. Schapira AH. Etiology of Parkinson's disease. Neurology 2006; 66(10 Suppl 4): S10-S23.

32. Su X, Federoff HJ, Maguire-Zeiss KA. Mutant alpha-synuclein overexpression mediates early proinflammatory activity. Neurotox Res 2009; 16: 238-254.

33. Gao HM, Kotzbauer PT, Uryu K, Leight S, Trojanowski JQ, Lee VM. Neuroinflammation and oxidation/nitration of alpha-synuclein linked to dopaminergic neurodegeneration. J Neurosci 2008; 28: 7687-7698.

34. Van Den Heuvel C, Thornton E, Vink R. Traumatic brain injury and Alzheimer's disease: a review. Prog Brain Res 2007; 161: 303-316.

35. Perry VH, Cunningham $\mathrm{C}$, Holmes $\mathrm{C}$. Systemic infections and inflammation affect chronic neurodegeneration. Nat Rev Immunol 2007; 7: 161-167.

36. Lemaitre B, Nicolas E, Michaut L, Reichhart JM, Hoffmann JA. The dorsoventral regulatory gene cassette spatzle/Toll/cactus controls the potent antifungal response in Drosophila adults. Cell 1996; 86: 973-983.

37. Kawai T, Akira S. TLR signaling. Cell Death Differ 2006; 13: 816-825.

38. Bsibsi M, Ravid R, Gveric D, van Noort JM. Broad expression of Toll-like receptors in the human central nervous system. J Neuropathol Exp Neurol 2002; 61: 1013-1021.

39. Akira S, Uematsu S, Takeuchi O. Pathogen recognition and innate immunity. Cell 2006; 124: 783-801.

40. Boulay JL, O'Shea JJ, Paul WE. Molecular phylogeny within type I cytokines and their cognate receptors. Immunity 2003; 19: 159-163.

41. Shuai K, Liu B. Regulation of JAK-STAT signalling in the immune system. Nat Rev Immunol 2003; 3: 900-911.

42. Yoshimura A, Naka T, Kubo M. SOCS proteins, cytokine signalling and immune regulation. Nat Rev Immunol 2007; 7: 454-465.

43. Stark GR. How cells respond to interferons revisited: from early history to current complexity. Cytokine Growth Factor Rev 2007; 18: 419-423.

44. Hu X, Paik PK, Chen J, Yarilina A, Kockeritz L, Lu TT et al. IFN-gamma suppresses IL-10 production and synergizes with TLR2 by regulating GSK3 and CREB/AP-1 proteins. Immunity 2006; 24: 563-574.

45. Pahl HL. Activators and target genes of Rel/NF-kappaB transcription factors. Oncogene 1999; 18: 6853-6866.

46. Ghosh S, Karin M. Missing pieces in the NF-kappaB puzzle. Cell 2002; 109(Suppl): S81-S96.

47. Dejardin E. The alternative NF-kappaB pathway from biochemistry to biology: pitfalls and promises for future drug development. Biochem Pharmacol 2006; 72: 1161-1179.

48. Chen L, Fischle W, Verdin E, Greene WC. Duration of nuclear NF-kappaB action regulated by reversible acetylation. Science 2001; 293: 1653-1657. 
49. Fuller $S$, Steele $M$, Munch $G$. Activated astroglia during chronic inflammation in Alzheimer's disease - do they neglect their neurosupportive roles? Mutat Res 2010; 690: 40-49.

50. Farina $\mathrm{C}$, Aloisi F, Meinl E. Astrocytes are active players in cerebral innate immunity. Trends Immunol 2007; 28: 138-145.

51. Brambilla R, Bracchi-Ricard V, Hu WH, Frydel B, Bramwell A, Karmally S et al. Inhibition of astroglial nuclear factor kappaB reduces inflammation and improves functional recovery after spinal cord injury. J Exp Med 2005; 202: 145-156.

52. van Loo G, De Lorenzi R, Schmidt $H$, Huth M, Mildner A, Schmidt-Supprian $M$ et al. Inhibition of transcription factor NF-kappaB in the central nervous system ameliorates autoimmune encephalomyelitis in mice. Nat Immunol 2006; 7: 954-961.

53. Lee HJ, Suk JE, Patrick C, Bae EJ, Cho JH, Rho S et al. Direct transfer of alpha-synuclein from neuron to astroglia causes inflammatory responses in synucleinopathies. $\mathrm{J} \mathrm{Biol}$ Chem 2010; 285: 9262-9272.

54. Saijo K, Winner B, Carson CT, Collier JG, Boyer L, Rosenfeld MG et al. A Nurr1/CoREST pathway in microglia and astrocytes protects dopaminergic neurons from inflammationinduced death. Cell 2009; 137: 47-59.

55. Cerretti DP, Kozlosky CJ, Mosley B, Nelson N, Van Ness K, Greenstreet TA et al. Molecular cloning of the interleukin-1 beta converting enzyme. Science 1992; 256: 97-100.

56. Thornberry NA, Bull HG, Calaycay JR, Chapman KT, Howard AD, Kostura MJ et al. A novel heterodimeric cysteine protease is required for interleukin-1 beta processing in monocytes. Nature 1992; 356: 768-774.

57. Martinon F, Tschopp J. Inflammatory caspases and inflammasomes: master switches of inflammation. Cell Death Differ 2007; 14: 10-22.

58. Schroder K, Tschopp J. The inflammasomes. Cell 2010; 140: 821-832.

59. Trendelenburg G. Acute neurodegeneration and the inflammasome: central processor for danger signals and the inflammatory response? J Cereb Blood Flow Metab 2008; 28 867-881.

60. Halle A, Hornung V, Petzold GC, Stewart CR, Monks BG, Reinheckel T et al. The NALP3 inflammasome is involved in the innate immune response to amyloid-beta. Nat Immunol 2008; 9: 857-865.

61. Salminen A, Ojala J, Suuronen T, Kaarniranta K, Kauppinen A. Amyloid-beta oligomers set fire to inflammasomes and induce Alzheimer's pathology. J Cell Mol Med 2008; 12 2255-2262.

62. Riedl SJ, Shi Y. Molecular mechanisms of caspase regulation during apoptosis. Nat Rev Mol Cell Biol 2004; 5: 897-907.

63. Mace PD, Riedl SJ. Molecular cell death platforms and assemblies. Curr Opin Cell Bio 2010; 22: 828-836.

64. Zimmermann KC, Bonzon C, Green DR. The machinery of programmed cell death. Pharmacol Ther 2001; 92: 57-70.

65. Miossec C, Dutilleul V, Fassy F, Diu-Hercend A. Evidence for CPP32 activation in the absence of apoptosis during T lymphocyte stimulation. J Biol Chem 1997; 272 13459-13462.

66. Kennedy NJ, Kataoka T, Tschopp J, Budd RC. Caspase activation is required for T cell proliferation. J Exp Med 1999; 190: 1891-1896.

67. Chun HJ, Zheng L, Ahmad M, Wang J, Speirs CK, Siegel RM et al. Pleiotropic defects in lymphocyte activation caused by caspase- 8 mutations lead to human immunodeficiency. Nature 2002; 419: 395-399.

68. Allombert-Blaise C, Tamiji S, Mortier L, Fauvel H, Tual M, Delaporte E et al. Terminal differentiation of human epidermal keratinocytes involves mitochondria- and caspasedependent cell death pathway. Cell Death Differ 2003; 10: 850-852.

69. Zandy AJ, Lakhani S, Zheng T, Flavell RA, Bassnett S. Role of the executioner caspases during lens development. J Biol Chem 2005; 280: 30263-30272.

70. Zermati Y, Garrido C, Amsellem S, Fishelson S, Bouscary D, Valensi F et al. Caspase activation is required for terminal erythroid differentiation. J Exp Med 2001; 193: 247-254.

71. Fernando P, Kelly JF, Balazsi K, Slack RS, Megeney LA. Caspase 3 activity is required for skeletal muscle differentiation. Proc Natl Acad Sci USA 2002; 99: 11025-11030.

72. Mogi M, Togari A. Activation of caspases is required for osteoblastic differentiation. J Bio Chem 2003; 278: 47477-47482.

73. Watanabe C, Shu GL, Zheng TS, Flavell RA, Clark EA. Caspase 6 regulates B cell activation and differentiation into plasma cells. J Immunol 2008; 181: 6810-6819.

74. Kang TB, Ben-Moshe T, Varfolomeev EE, Pewzner-Jung Y, Yogev N, Jurewicz A et al. Caspase-8 serves both apoptotic and nonapoptotic roles. J Immunol 2004; 173 2976-2984.

75. Murray TV, McMahon JM, Howley BA, Stanley A, Ritter T, Mohr A et al. A non-apoptotic role for caspase-9 in muscle differentiation. J Cell Sci 2008; 121 (Pt 22): 3786-3793.

76. Su H, Bidere N, Zheng L, Cubre A, Sakai K, Dale J et al. Requirement for caspase-8 in NF-kappaB activation by antigen receptor. Science 2005; 307: 1465-1468.

77. Barbero S, Mielgo A, Torres V, Teitz T, Shields DJ, Mikolon D et al. Caspase-8 association with the focal adhesion complex promotes tumor cell migration and metastasis. Cancer Res 2009; 69: 3755-3763.

78. Pellegrini M, Bath S, Marsden VS, Huang DC, Metcalf D, Harris AW et al. FADD and caspase-8 are required for cytokine-induced proliferation of hemopoietic progenitor cells. Blood 2005; 106: 1581-1589.
79. Oomman S, Finckbone V, Dertien J, Attridge J, Henne W, Medina M et al. Active caspase-3 expression during postnatal development of rat cerebellum is not systematically or consistently associated with apoptosis. J Comp Neurol 2004; 476: 154-173.

80. Li Z, Jo J, Jia JM, Lo SC, Whitcomb DJ, Jiao S et al. Caspase-3 activation via mitochondria is required for long-term depression and AMPA receptor internalization. Cell 2010; 141: 859-871.

81. D'Amelio M, Cavallucci V, Middei S, Marchetti C, Pacioni S, Ferri A et al. Caspase-3 triggers early synaptic dysfunction in a mouse model of Alzheimer's disease. Nat NeurosCi 2011; 14: 69-76.

82. Oomman S, Strahlendorf $\mathrm{H}$, Dertien J, Strahlendorf J. Bergmann glia utilize active caspase-3 for differentiation. Brain Res 2006; 1078: 19-34.

83. Acarin L, Villapol S, Faiz M, Rohn TT, Castellano B, Gonzalez B. Caspase-3 activation in astrocytes following postnatal excitotoxic damage correlates with cytoskeletal remodeling but not with cell death or proliferation. Glia 2007; 55: 954-965.

84. Rohn TT, Kokoulina P, Eaton CR, Poon WW. Caspase activation in transgenic mice with Alzheimer-like pathology: results from a pilot study utilizing the caspase inhibitor Q-VD-OPh. Int J Clin Exp Med 2009; 2: 300-308.

85. Ona VO, Li M, Vonsattel JP, Andrews LJ, Khan SQ, Chung WM et al. Inhibition of caspase-1 slows disease progression in a mouse model of Huntington's disease. Nature 1999; 399: 263-267.

86. Schierle GS, Hansson O, Leist M, Nicotera P, Widner H, Brundin P. Caspase inhibition reduces apoptosis and increases survival of nigral transplants. Nat Med 1999; 5: 97-100.

87. Li M, Ona VO, Guegan C, Chen M, Jackson-Lewis V, Andrews LJ et al. Functional role of caspase-1 and caspase-3 in an ALS transgenic mouse model. Science 2000; 288 335-339.

88. Braun JS, Prass K, Dirnagl U, Meisel A, Meisel C. Protection from brain damage and bacterial infection in murine stroke by the novel caspase-inhibitor Q-VD-OPH. Exp Neuro 2007; 206: 183-191.

89. Schulz JB, Weller M, Matthews RT, Heneka MT, Groscurth P, Martinou JC et al. Extended therapeutic window for caspase inhibition and synergy with MK-801 in the treatment of cerebral histotoxic hypoxia. Cell Death Differ 1998; 5: 847-857.

90. Wu DC, Jackson-Lewis V, Vila M, Tieu K, Teismann P, Vadseth C et al. Blockade of microglial activation is neuroprotective in the 1-methyl-4-phenyl-1,2,3,6-tetrahydropyridine mouse model of Parkinson disease. J Neurosci 2002; 22: 1763-1771.

91. Gribble GW. Fluoroacetate toxicity. J Chem Educ 1973; 50: 460-462.

92. Chauvier D, Ankri S, Charriaut-Marlangue C, Casimir R, Jacotot E. Broad-spectrum caspase inhibitors: from myth to reality? Cell Death Differ 2007; 14: 387-391.

93. Yang L, Sugama S, Mischak RP, Kiaei M, Bizat N, Brouillet E et al. A novel systemically active caspase inhibitor attenuates the toxicities of MPTP, malonate, and 3NP in vivo. Neurobiol Dis 2004; 17: 250-259.

94. Colak A, Antar V, Karaoglan A, Akdemir O, Sahan E, Celik O et al. Q-VD-OPh, pancaspase inhibitor, reduces trauma-induced apoptosis and improves the recovery of hind-limb function in rats after spinal cord injury. Neurocirugia (Astur) 2009; 20: 533-540; discussion 540.

95. Yrjanheikki J, Keinanen R, Pellikka M, Hokfelt T, Koistinaho J. Tetracyclines inhibit microglial activation and are neuroprotective in global brain ischemia. Proc Natl Acad Sci USA 1998; 95: 15769-15774.

96. Festoff BW, Ameenuddin S, Arnold PM, Wong A, Santacruz KS, Citron BA. Minocycline neuroprotects, reduces microgliosis, and inhibits caspase protease expression early after spinal cord injury. J Neurochem 2006; 97: 1314-1326.

97. Gordon PH, Moore DH, Miller RG, Florence JM, Verheijde JL, Doorish C et al. Efficacy of minocycline in patients with amyotrophic lateral sclerosis: a phase III randomised trial. Lancet Neurol 2007; 6: 1045-1053.

98. Couzin J. Clinical research. ALS trial raises questions about promising drug. Science 2007; 318: 1227

99. Investigators. NN-P. A pilot clinical trial of creatine and minocycline in early Parkinson disease: 18-month results. Clin Neuropharmacol 2008; 31: 141-150.

100. Investigators HSGD. A futility study of minocycline in Huntington's disease. Mov Disord 2010; 25: 2219-2224.

101. Kim SS, Ye C, Kumar P, Chiu I, Subramanya S, Wu H et al. Targeted delivery of siRNA to macrophages for anti-inflammatory treatment. Mol Ther 2010; 18: 993-1001.

102. Karatas H, Aktas Y, Gursoy-Ozdemir Y, Bodur E, Yemisci M, Caban S et al. A nanomedicine transports a peptide caspase-3 inhibitor across the blood-brain barrier and provides neuroprotection. J Neurosci 2009; 29: 13761-13769.

103. McGeer PL, Itagaki S, Boyes BE, McGeer EG. Reactive microglia are positive for HLA-DR in the substantia nigra of Parkinson's and Alzheimer's disease brains. Neurology 1988; 38: $1285-1291$.

104. Perry VH, Nicoll JA, Holmes C. Microglia in neurodegenerative disease. Nat Rev Neurol 2010; 6: 193-201.

105. Okun E, Griffioen KJ, Lathia JD, Tang SC, Mattson MP, Arumugam TV. Toll-like receptors in neurodegeneration. Brain Res Rev 2009; 59: 278-292.

106. Meda L, Cassatella MA, Szendrei Gl, Otvos Jr L, Baron P, Villalba M et al. Activation of microglial cells by beta-amyloid protein and interferon-gamma. Nature 1995; 374 647-650.

107. Udan ML, Ajit D, Crouse NR, Nichols MR. Toll-like receptors 2 and 4 mediate Abeta(1-42) activation of the innate immune response in a human monocytic cell line. J Neurochem 2008; 104: 524-533. 
108. Fassbender K, Walter S, Kuhl S, Landmann R, Ishii K, Bertsch T et al. The LPS receptor (CD14) links innate immunity with Alzheimer's disease. FASEB J 2004; 18 203-205.

109. Papadimitriou D, Le Verche V, Jacquier A, Ikiz B, Przedborski S, Re DB. Inflammation in ALS and SMA: sorting out the good from the evil. Neurobiol Dis 2010; 37: 493-502.

110. Maihofner C, Probst-Cousin S, Bergmann M, Neuhuber W, Neundorfer B, Heuss D. Expression and localization of cyclooxygenase-1 and -2 in human sporadic amyotrophic lateral sclerosis. Eur J Neurosci 2003; 18: 1527-1534.

111. Sekizawa T, Openshaw H, Ohbo K, Sugamura K, Itoyama Y, Niland JC. Cerebrospina fluid interleukin 6 in amyotrophic lateral sclerosis: immunological parameter and comparison with inflammatory and non-inflammatory central nervous system diseases. J Neurol Sci 1998; 154: 194-199.

112. Kostic V, Jackson-Lewis V, de Bilbao F, Dubois-Dauphin M, Przedborski S. Bcl-2 prolonging life in a transgenic mouse model of familial amyotrophic lateral sclerosis Science 1997; 277: 559-562.

113. Stadelmann C, Wegner C, Bruck W. Inflammation, demyelination, and degeneration recent insights from MS pathology. Biochim Biophys Acta 2011; 1812: 275-282.
114. Hill KE, Zollinger LV, Watt HE, Carlson NG, Rose JW. Inducible nitric oxide synthase in chronic active multiple sclerosis plaques: distribution, cellular expression and association with myelin damage. J Neuroimmunol 2004; 151: 171-179.

115. Rose JW, Hill KE, Watt HE, Carlson NG. Inflammatory cell expression of cyclooxygenase2 in the multiple sclerosis lesion. J Neuroimmunol 2004; 149: 40-49.

116. International AsD. Annual World Alzheimer Report 2010; Alzheimer's Disease International (ADI): London.

117. Sobocki P, Pugliatti M, Lauer K, Kobelt G. Estimation of the cost of MS in Europe: extrapolations from a multinational cost study. Multi Scler 2007; 13: 1054-1064.

118. Schepelmann K, Winter Y, Spottke AE, Claus D, Grothe C, Schroder R et al. Socioeconomic burden of amyotrophic lateral sclerosis, myasthenia gravis and facioscapulohumeral muscular dystrophy. J Neurol 2010; 257: 15-23.

119. Chen JJ. Parkinson's disease: health-related quality of life, economic cost, and implications of early treatment. Am J Manag Care 2010; 16(Suppl Implications): S87-S93.

120. Salmena L, Lemmers B, Hakem A, Matysiak-Zablocki E, Murakami K, Au PY et al. Essential role for caspase 8 in T-cell homeostasis and T-cell-mediated immunity. Genes Dev 2003; 17: 883-895. 